\title{
Hubungan Antara Kepatuhan Mengkonsumsi Tablet Fe Dengan Tingkat Kejadian Perdarahan Pada Ibu Hamil Trimester III
}

\author{
Wahidah.S.Pd.,M.Kes \\ Wahidahstikesyahyabima@yahoo.com, \\ STIKES YAHYA BIMA \\ NIDN. 0824118502
}

\begin{abstract}
Abstrak: Angka Kematian Ibu (AKI) merupakan salah satu indikator keberhasilan layanan kesehatan di suatu negara. Kematian ibu dapat terjadi karena beberapa sebab, diantaranya karena anemia. Angka kematian ibu menunjukkan bahwa angka kematian ibu adalah 70\% untuk ibu-ibu yang anemia dan 19,7\% untuk mereka yang non anemia. Kematian ibu 15-20\% secara langsung atau tidak langsung berhubungan dengan anemia. Anemia pada kehamilan juga berhubungan dengan meningkatnya kesakitan ibu (Varney, 2016). Penelitian ini menggunakan metode Observasional Analitik dengan pendekatan Longitudinal karena peneliti ingin mengetahui Hubungan kepatuhan konsumsi tablet Fe pada ibu hamil trimester III terhadap tingkat kejadian perdarahan persalinan di Puskesmas Woha, Kecamatan Woha, Kabupaten Bima. Jumlah sampel dalam penelitian ini adalah 23 orang ibu hamil yang berada di Puskesmas Woha, Kecamatan Woha, Kabupaten Bima. Hasil Analisis statistik dengan uji Chi Squart test menunjukkan bahwa nilai $p=0,03$ dan nilai $\alpha=0,05$ yang berarti $p<\alpha$ dengan demikian Ho ditolak dan $\mathrm{Ha}$ diterima, berarti dapat disimpulkan bahwa ada hubungan antara kepatuhan mengkonsumsi tablet $\mathrm{Fe}$ dengan tingkat kejadian perdarahan pada ibu hamil trimester III. Sarandiharapkan hasil penelitian ini dapat memberikan ilmu yang baru untuk menelaah lebih lanjut kepatuhan mengkonsumsi tablet $\mathrm{Fe}$
\end{abstract}

Kata kunci : Kepatuhan Konsumsi, Pendarahan Pada Hamil

\section{Pendahuluan}

Angka Kematian Ibu (AKI) merupakan salah satu indikator keberhasilan layanan kesehatan di suatu negara. Kematian ibu dapat terjadi karena beberapa sebab, diantaranya karena anemia. Angka kematian ibu menunjukkan bahwa angka kematian ibu adalah 70\% untuk ibu-ibu yang anemia dan 19,7\% untuk mereka yang non anemia. Kematian ibu 15-20\% secara langsung atau tidak langsung berhubungan dengan anemia. Anemia pada kehamilan juga berhubungan dengan meningkatnya kesakitan ibu (Varney, 2016).

Perdarahan menempati persentase tertinggi penyebab kematianibu (28\%). Anemia dan kekurangan energikronis (KEK) pada ibu hamil menjadi penyebab utama terjadinya perdarahan daninfeksi yang merupakan faktor kematian utama ibu.Di berbagainegara paling sedikit 
seperempat dari seluruh kematian ibu disebabkan oleh perdarahan, proporsinya berkisar antara kurang dari 10\% sampai hampir 60\%. Walaupun seorang perempuan bertahan hidup setelah mengalami perdarahan pasca persalina, namun ia akan menderita akibat kekurangan darah yang berat (anemia berat) dan akan mengalami masalah kesehatan yang berkepanjangan (WHO, 2012).

Anemia dalam kehamilan merupakan kondisi ibu dengan kadar haemoglobin dibawah 11 gr $\%$ pada trimester I dan III atau kadar $<10,5 \mathrm{gr} \%$ pada trimester II. Anemia dalam kehamilan yang disebabkan karena kekurangan zat besi, jenis pengobatannya relatif mudah, bahkan murah. Yang sering terjadi adalah anemia karena kekurangan zat besi (Prawirohardjo, 2013).

Penyebab anemia yang paling banyak dijumpai di Indonesia adalah anemia akibat kekurangan zat besi. Hal ini dikarenakan masukan melalui makanan yang masih kurang maupun karena kebutuhan yang meningkat, serta kurangnya konsumsi pemacu penyerapan zat besi seperti proteIn hewani dan vitamin C (Wibowo, 2013).

Dampak anemia dalam kehamilan adalah dapat terjadi keguguran. Dampak anemia dalam persalinan adalah kelahiran premature, inertia uteri, atonia uteri, partus lama, perdarahan atonis dan kelahiran dengan BBLR (Berat Bayi Lahir Rendah) dengan kondisi bayi yang lemah. desangkan Dampak anemia pada masa nifas adalah subinvolusio rahim, daya tahan terhadap infeksi, produksi ASI rendah dan stress (Prawiraharjo, 2012).

Oleh karena itu anemia harus diatasi karena berbahaya bagi ibu dan janin. Pemerintah Indonesia sudah melakukan upaya upaya pencegahan dan penanggulangan anemia dalam kehamilan sejak tahun 1975. Usaha tersebut dengan memberikan suplemen vitamin (B6,B12) dan mineral (asam folat, tablet besi). Vitamin dan mineral tersebut digunakan untuk pembentukkan sel darah merah. Ibu hamil dapat memperoleh tablet besi di Puskesmas atau posyandu ibu hamil. Tablet besi diberikan sebanyak 90 butir untuk selama kehamilan sampai 42 hari masa nifas dengan dosis 1x1 perhari (Depkes, 2014). Walaupun pemerintah sudah melakukan upaya-upaya untuk mengatasi anemia dalam kehamilan, akan tetapi prevalensi anemia masih tinggi (Triratnawati, 2015).

Kondisi ini disebabkan karena adanya persepsi yang salah pada ibu hamil dan adanya ketidak tepatan perilaku ibu hamil ketika minum tablet besi (WHO, 2012), Selain itu juga karena kurangnya penyuluhan kepada ibu hamil baik diperkotaan maupun dipedesaan, kurangnya peran petugas kesehatan dalam memotivasi ibu hamil untuk minum tablet besi dan kepatuhan ibu hamil selama mengkonsumsi tablet besi masih relatif rendah (Wigyosastro, 2015).

Anemia pada umumnya terjadi di seluruh dunia terutama di negara di negara berkembang (Devoloping Countries) dan pada kelompok dewasa anemia terjadi pada wanita usia 
reproduksi terutama wanita hamil dan wanita menyususi karena mereka banyak yang mengalami defisisensi Fe. Secara keseluruhan anemia terjadi 45\% wanita di negara berkembang, 13\% di negara maju. Di Amerika terdapat 12\% wanita usia subur 15-49 tahun, 11\% wanita usia subur mengalami wanita, sementara presentase wanita hamil dari kalangan miskin terus meningkat seiring bertambahnya usia kehamilan 18\% anemia trimester I, 12\% anemia trimester II, dan 29\% anemia trimester III. Anemia pada wanita masa nifas / pasca persalinan dan juga terjadi sekitar 10\% dan 20\% terjadi pada ibu post partum dari keluarga miskin. Komplikasi yang paling sering terjadi adalah seperti perdarahan, infeksi, abortus, dan partus lama sekitar 90\% (Depkes, 2011).

Menurut WHO 40\% kematian ibu di Negara berkembang berkaitan dengan anemia pada kehamilan dan kebanyakan anemia pada kehamilan disebabkan oleh defisiensi zat besi dan perdarahan akut, bahkan tak jarang keduanya memberikan pengaruh kurang baik bagi ibu, baik dalam kehamilan, persalinan, maupun dalam masa nifas dan masa selanjutnya. Prevalensi anemia defisiensi besi (ADB ) pada kehamilan di Negara maju rata-rata 13\% (Baker, 2011).

Angka kematian ibu (AKI) dan angka kematian bayi (AKB) merupakan salah satu indikator keberhasilan layanan kesehatan di suatu Negara. Angka kematian ibu (AKI) indonesia Relatif tinggi dibandingkan dengan negara lain di ASEAN yaitu sebesar 263 per 100.000 kelahiran hidup (SKRT, 2011).

Di Indonesia diperkirakan setiap harinya terjadi 41 kasus anemia, dan 20 perempuan meninggal dunia karena kondisi tersebut. Tingginya angka ini disebabkan oleh rendah pengetahuan dan kesadaran akan bahaya anemia dalam kehamilan. anemia dalam kehamilan cenderung muncul pada pada kehamilan TM I dan III (Yuliatin, 2011).

NTB jumlah penderita anemia pada 2012 sebanyak 29 orang, meningga. Sedangkan pada tahun 2013 anemia sebanyak 37 orang, dan pada tahun 2014 penderita anemia sebanyak 27. Pada tahun 2016 penderita anemia sebanyak 29 orang, sedangkan pada tahun 2017 ibu hamil yang menderita anemia mengalami peningkatan sebanyak 34 orang (Laporan Dinas Kesehatan Propinsi NTB).

\section{Metodologi Penelitian}

Penelitian ini menggunakan metode Observasional Analitik dengan pendekatan Longitudinal karena peneliti ingin mengetahui Hubungan kepatuhan konsumsi tablet Fe pada ibu hamil trimester III terhadap tingkat kejadian perdarahan persalinan di Puskesmas Woha, Kecamatan Woha, Kabupaten Bima. Jumlah sampel dalam penelitian ini adalah 23 orang ibu hamil yang berada di Puskesmas Woha, Kecamatan Woha, Kabupaten Bima. 


\section{Hasil Penelitian dan Pembahasan}

5.1 Karakteristik Umum Responden

Tabel 5.1 Distribusi Responden Berdasarkan umur

\begin{tabular}{lll}
\hline Umur & Frekuensi (n) & Persentase \% \\
\hline$<20$ Tahun & 2 & 8.7 \\
$21-30$ Tahun & 13 & 56.5 \\
$>31$ Tahun & 8 & 34.8 \\
\hline Jumlah & 23 & 100.0
\end{tabular}

Sumber:Data Primer

Berdasarkan tabel 5.1 menunjukan bahwa dari 23 responden diketahui bahwa 2 responden $(8.7 \%)$ yang berumur $<20$ Tahun, 13 responden $(56.5 \%)$ yang berumur $21-30$ tahun, 8 responden $(34.8 \%)$ yang berumur $>31$ tahun. Sebagian besar umur responden dengan frekuensi tertinggi adalah responden yang berumur 21 - 30 Tahun sebanyak 13 responden.

Tabel 5.2 Distribusi Frekuensi Pendidikan Respoden

\begin{tabular}{lll}
\hline Pendidikan & Frekuensi (n) & Persentase \% \\
\hline PT & 1 & 4.3 \\
SMA & 9 & 39.1 \\
SMP & 11 & 47.8 \\
SD & 2 & 8.7 \\
\hline Jumlah & 23 & 100.0 \\
\hline
\end{tabular}

Sumber:Data Primer

Berdasarkan tabel 5.2 menunjukan bahwa dari 23 responden diketahui bahwa 1 responden (4.3\%) yang berpendidikan perguruan tinggi, 9 responden $(39.1 \%)$ yang berpendidikan SMA, 11 responden (47.8\%) yang berpendidikan SMP, 2 responden $(8.7 \%)$ yang berpendidikan SD. Sebagian besar pendidikan responden dengan frekuensi tertinggi adalah responden yang berpendidikan SMP sebanyak 11 responden. 
Tabel 5.3 Distribusi Frekuensi Pekerjaan Respoden

\begin{tabular}{lll}
\hline Pekerjaan & Frekuensi (n) & Persentase \% \\
\hline IRT & 17 & 73.9 \\
Pedagang & 4 & 17.4 \\
PNS & 2 & 8.7 \\
\hline Jumlah & 23 & 100.0 \\
\hline
\end{tabular}

Sumber:Data Primer

Berdasarkan tabel 5.3 bahwa dari 23 responden diketahui bahwa 17 responden (73.9\%) yang bekerja sebagai IRT, 4 responden (17.4\%) yang bekerja sebagai pedagang, 2 responden $(8.7 \%)$ yang bekerja sebagai PNS. Sebagian besar pekerjaan responden dengan frekuensi tertinggi adalah responden yang bekerja sebagai IRT sebanyak 17 responden

5.2 Karakteristik Khusus Responden

Tabel 5.4 Distribusi Responden Berdasarkan Kepatuhan Mengkonsumsi Tablet Fe

\begin{tabular}{lll}
\hline Kepatuhan Konsumsi Fe & Frekuensi (n) & Persentase \% \\
\hline Tidak Patuh & 9 & 39.1 \\
Patuh & 14 & 60.9 \\
\hline Jumlah & 23 & 100.0
\end{tabular}

Sumber:Data Primer

Berdasarkan tabel 5.4 dari 23 responden diketahui bahwa 9 responden $(39.1 \%)$ yang tidak patuh mengkonsumsi tablet Fe, 14 responden (60.9\%) yang patuh mengkonsumsi tablet Fe. Sebagian besar responden dengan frekuensi tertinggi adalah responden yang patuh mengkonsumsi tablet Fe sebanyak 14 responden.

Tabel 5.5 Distribusi Responden Berdasarkan Tingkat Kejadian Perdarahan

\begin{tabular}{lll}
\hline Kejadian Perdarahan & Frekuensi (n) & Persentase (\%) \\
\hline Tidak & 7 & 30.4 \\
Mengalami & 16 & 69.6 \\
\hline Jumlah & 23 & 100.0
\end{tabular}

\section{Sumber:Data Primer}

Berdasarkan tabel 5.5 dari 23 responden diketahui bahwa 7 responden (30.4\%) yang tidak mengalami kejadian perdarahan, 16 responden (69.6\%) yang mengalami kejadian perdarahan. Sebagian besar responden dengan frekuensi tertinggi adalah responden yang mengalami kejadian perdarahan. 
5.3 Hubungan kepatuhan mengkonsumsi tablet Fe dengan tingkat kejadian perdarahan

Analisis ini dilakukan untuk mengetahui hubungan antara variabel independen dan dependen. Dalam penelitian ini sebagai variabel independennya adalah kepatuhan mengkonsumsi tablet Fe sedangkan variabel dependen adalah kejadian perdarahan.

Tabel 5.6 Hubungan antara kepatuhan mengkonsumsi tablet Fe dengan kejadian perdarahan

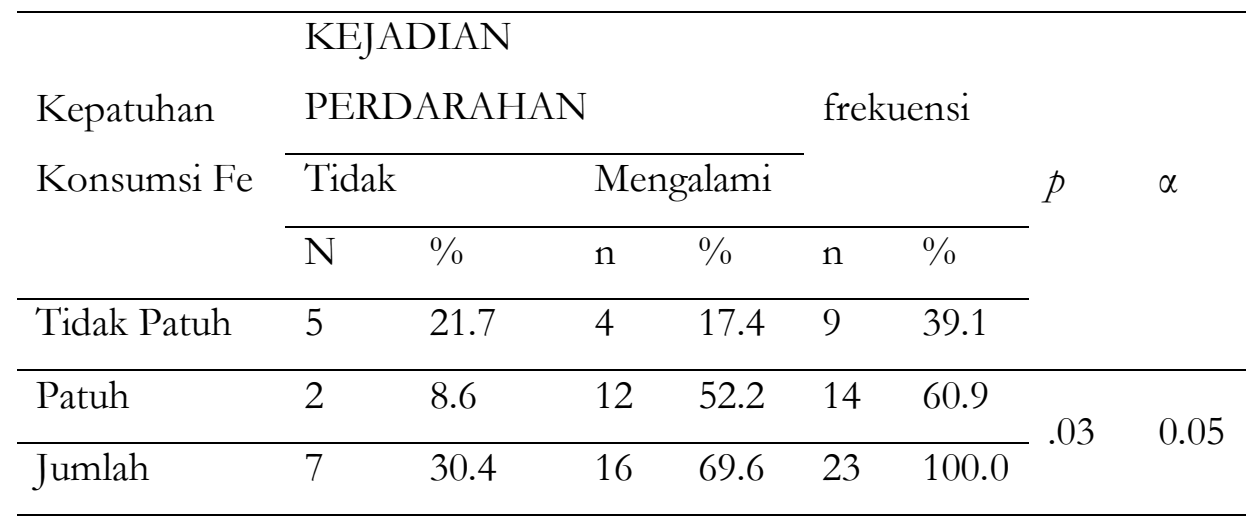

Sumber:Data Primer

Pada tabel 5.6 menunjukkan bahwa dari 9 responden (39.1\%) yang tidak patuh mengkonsumsi tablet Fe, 5 responden $(21.7 \%)$ yang tidak mengalami perdarahan, 4 responden $(17.4 \%)$ yang mengalami perdarahan. 14 responden $(60.9 \%)$ yang patuh mengkonsumsi tablet $\mathrm{Fe}, 2$ responden $(8.6 \%)$ yang tidak mengalami kejadian perdarahan, 12 responden $(52.2 \%)$ yang mengalami kejadian perdarahan.

Hasil Analisis statistik dengan uji Chi Squart test menunjukkan bahwa nilai $p=0,03$ dan nilai $\alpha=0,05$ yang berarti $p<\alpha$ dengan demikian Ho ditolak dan $\mathrm{Ha}$ diterima, berarti dapat disimpulkan bahwa ada hubungan antara kepatuhan mengkonsumsi tablet Fe dengan tingkat kejadian perdarahan pada ibu hamil trimester III.

1. Kepatuhan konsumsi tablet Fe pada ibu hamil trimester III

Berdasarkan tabel 5.4 dari 23 responden diketahui bahwa 9 responden (39.1\%) yang tidak patuh mengkonsumsi tablet Fe, 14 responden (60.9\%) yang patuh mengkonsumsi tablet Fe. Sebagian besar responden dengan frekuensi tertinggi adalah responden yang patuh mengkonsumsi tablet Fe sebanyak 14 responden..

Penelitian ini sejalan dengan pendapat Niven (2014), yang mengatakan bahwaTidak seorang pun dapat mematubi instruksi jika ia salah paham tentang instruksi yang diberikan padanya. Kadang-kadang hal ini disebabkan oleh kegagalan profesional kesehatan dalam memberikan informasi yang kurang lengkap, penggunaan istilah-istilah medis dan memberikan banyak instruksi yang harus 
diingat pasien Kualitas informasi antara profesional kesehatan dan pasien merupakan bagian yang penting dalam menentukan derajat kepatuban.

Derajat di mana seseorang terisolasi dari pendampingan, isolasi sosial, secara negative berbubungan dengan kepatuhan. Anggota anggota jaringan sosial individu sering kali mempengarubi seseorang dalam mencari pelayanan kesehatan. Jaringan kerja rujukan biasa terdiri dari sekelompok orang, biasanya keluarga atau teman, di mana seseorang pertama kali menceritakan keluhannya dan meminta nasibat. Bagaimanapun, dalam kaitannya dengan kepatuhan, perlu dicatat babwa jaringan kerja rujukan biasa telab berperan penting dalam penentuan keputusan untuk mencari dan mematubi anjuran pengobatan.

Responden yang mengkonsumsi tablet $\mathrm{Fe}$ di wilayah kerja puskesmas Woba dilihat dari tingkat kepatuban mengkonsumsi tablet Fe menunjukan bahwa hampir sebagian dari ibu - ibu bamil sadar akan pentingnya tablet $\mathrm{Fe}$ untuk dikonsumsi pada saat hamil. Hal ini ditunjukan dengan hasil penelitian babwa dari 32 responden terdapat 14 responden yang sadar untuk menkonsumsi tablet $\mathrm{Fe}$ dan 9 tidak. patuh mengkonsumsi tablet $\mathrm{Fe}$.

Selain memberikan dampak pada kejadian perdarahan, tablet Fe juga dapat memberikan dampak yang positif terbadap ibu hamil bila dikonsumsi secara rutin pada saat hamil, lebih - lebih pada trimester III. Pada masa ini ibu bamil lebih banyak membutubkan zat besi yang menunjang pertumbuban dan perkembangan janin.

Tablet Fe merupakan vitamin dan mineral penting bagi wanita hamil untuk mencegah kecacatan pada perkembangan bayi baru lahir dan kematian ibu yang disebabkan oleh anemia berat (Ami, 2011). Oleh karena itu, tablet ini sangat diperlukan ibu hamil. Sudah selayaknya seorang ibu hamil akan mendapatkan 90 tablet Fe selama masa kehamilannya (Hunter dkk, 2011).

Dampak anemia dalam kehamilan adalah dapat terjadi keguguran. Dampak anemia dalam persalinan adalah kelahiran premature, inertia uteri, atonia uteri, partus lama, perdarahan atonis dan kelahiran dengan BBLR (Berat Bayi Lahir Rendah) dengan kondisi bayi yang lemah. Sedangkan Dampak anemia pada masa nifas adalah subinvolusio rahim, daya tahan terhadap infeksi, produksi ASI rendah dan stress

2. Tingkat Kejadian Perdarahan

Berdasarkan tabel 5.5 dari 23 responden diketahui bahwa 7 responden (30.4\%) yang tidak mengalami kejadian perdarahan, 16 responden (69.6\%) yang mengalami kejadian perdarahan. Sebagian besar responden dengan frekuensi tertinggi adalah responden yang mengalami kejadian perdarahan. 
Hasil penelitian ini sejalan dengan data (WHO, 2012) bahwa perdarahan menempati persentase tertinggi penyebab kematianibu (28\%). Anemia dan kekurangan energikronis (KEK) pada ibu hamil menjadi penyebab utama terjadinya perdarahan daninfeksi yang merupakan faktor kematian utama ibu. Di berbagai Negara paling sedikit seperempat dari seluruh kematian ibu disebabkan oleh pendarahan, proporsinya berkisar antara kurang dari $10 \%$ sampai hampir 60\%. Walaupun seorang perempuan bertahan hidup setelah mengalami perdarahan pasca persalina, namun ia akan menderita akibat kekurangan darah yang berat (anemia berat) dan akan mengalami masalah kesehatan yang berkepanjangan.

Biasanya tanda dan gejala subinvolusi tidak tampak, sampai kira-kira 4 hingga 6 minggu pascapartum.Fundus uteri letaknya tetap tinggi di dalam abdomen/ pelvis dari yang diperkirakan. Keluaran lochea seringkali gagal berubah dari bentuk rubra ke bentuk serosa, lalu ke bentuk lochea alba. Lochea bisa tetap dalam bentuk rubra, atau kembali ke bentuk rubra dalam beberapa hari pacapartum. Lochea yang tetap bertahan dalam bentuk rubra selama lebih dari 2 minggu pascapatum sangatlah perlu dicurigai terjadi kasus subinvolusi.Jumlah lochea bisa lebih banyak dari pada yang diperkirakan.Leukore, sakit punggung, dan lochea berbau menyengat, bisa terjadi jika ada infeksi.Ibu bisa juga memiliki riwayat perdarahan yang tidak teratur, atau perdarahan yang berlebihan setelah kelahiran(Abdul Bari, dkk, 2015).

Perdarahan menempati persentase tertinggi penyebab kematianibu (28\%). Anemia dan kekurangan energikronis (KEK) pada ibu hamil menjadi penyebab utama terjadinya perdarahan daninfeksi yang merupakan faktor kematian utama ibu.Di berbagainegara paling sedikit seperempat dari seluruh kematian ibu disebabkan oleh perdarahan, proporsinya berkisar antara kurang dari 10\% sampai hampir 60\%. Walaupun seorang perempuan bertahan hidup setelah mengalami perdarahan pasca persalinan, namun ia akan menderita akibat kekurangan darah yang berat (anemia berat) dan akan mengalami masalah kesehatan yang berkepanjangan (WHO, 2012).

Anemia harus diatasi karena berbahaya bagi ibu dan janin. Pemerintah Indonesia sudah melakukan upaya upaya pencegahan dan penanggulangan anemia dalam kehamilan sejak tahun 1975. Usaha tersebut dengan memberikan suplemen vitamin (B6,B12) dan mineral (asam folat, tablet besi). Vitamin dan mineral tersebut digunakan untuk pembentukkan sel darah merah. Ibu hamil dapat memperoleh tablet besi di Puskesmas atau posyandu ibu hamil. Tablet besi diberikan sebanyak 90 butir untuk selama kehamilan sampai 42 hari masa nifas dengan dosis $1 \mathrm{x} 1$ perhari. Walaupun pemerintah sudah melakukan upayaupaya untuk mengatasi anemia dalam kehamilan, akan tetapi prevalensi anemia masih tinggi. 
Trimester ketiga sering kali disebut periode waspada sebab pada saat itu ibu merasa tidak sabar menunggu kelahiran bayinya. Gerakan bayi dan membesarnya perut merupakan 2 hal yang mengingatkan ibu akan bayinya. Kadang-kadang ibu merasa khawatir bahwa bayinya akan lahir sewaktu-waktu, ini menyebabkan ibu meninggkatkankewaspadaan akan timbulnya tanda dan gejala akan terjadi persalinan, ibu sering kali mersa khawatir atau kalau bayi yang akan dilahirkannya tidak normal.

Kebanyakan anemia dalam kehamilan disebabkan oleh defisiensi besi dan perdarahan akut bahkan tidak jarang keduannya saling berinteraksi (Safuddin, 2013).

3. Hubungan kepatuhan mengkonsumsi tablet Fe dengan tingkat kejadian perdarahan pada ibu hamil trimester III

Hasil Analisis statistik dengan uji Chi Squart test menunjukkan bahwa nilai $p=0,03$ dan nilai $\alpha=0,05$ yang berarti $p<\alpha$ dengan demikian Ho ditolak dan Ha diterima, berarti dapat disimpulkan bahwa ada hubungan antara kepatuhan mengkonsumsi tablet Fe dengan tingkat kejadian perdarahan pada ibu hamil trimester III. Hal ini menunjukan bahwa ibu hamil yang patuh mengkonsumsi tablet Fe, tidak akan mengalami perdarahan. Sedangkan ibu hamil yang tidak patuh mengkonsumsi tablet Fe, maka akan mengalami perdarahan.

Hasil penelitian ini sejalan dengan pendapat (Wibowo, 2013), bahwa penyebab anemia yang paling banyak dijumpai di Indonesia adalah anemia akibat kekurangan zat besi. Hal ini dikarenakan masukan melalui makanan yang masih kurang maupun karena kebutuhan yang meningkat, serta kurangnya konsumsi pemacu penyerapan zat besi seperti proteIn hewani dan vitamin $C$.

Tablet Fe merupakan mineral yang dibutuhkan untuk membentuk sel darah merah (bemoglobin). Selain itu, mineral ini juga berperan sebagai komponen untuk membentuk mioglobin (protein yang membawa oksigen ke otot), kolagen (protein yang terdapat di tulang, tulang rawan, dan jaringan penyambung), serta enzim. Tablet Fe juga berfungsi dalam sistim pertahanan tubuh. Tablet Fe sangat penting bagi kesehatan ibu hamil, diantaranya: mencegah terjadinya anemia defisiensi besi, mencegah terjadinya perdarahan pada saat persalinan dan dapat meningkatkan asupan nutrisi bagi janin.

Untuk para ibu hamil perlu mengkonsumsi makanan yang mengandung tinggi Fe.Seperti: daging merah, hati, sayuran hijau, kacang-kacangan dan mengkonsumsi cukup vitamin c juga penting, dimana vitamin c dapat membantu dalam penyerapan $\mathrm{Fe}$ itu sendiri (Rukiah dkk, 2014). 
Kebutuhan zat besi pada wanita hamil yaitu rata-rata mendekatai $800 \mathrm{mg}$. Kebutuhan ini terdiri dari, sekitar $300 \mathrm{mg}$ diperlukan untuk janin dan plasenta serta $500 \mathrm{mg}$ lagi digunakan untuk meningkatkan massa haemoglobin maternal. Kurang lebih 200 mg lebih akan dieksresikan lewat usus, urin dan kulit. Makanan ibu hamil setiap 100 kalori akan menghasilkan sekitar 8-10 mg zat besi. Perhitungan makan 3 kali dengan 2500 kalori akan menghasilkan sekitar 20-25 mg zat besi perhari. Selama kehamilan dengan perhitungan 288 hari, ibu hamil akan menghasilkan zat besi sebanyak $100 \mathrm{mg}$ sehingga kebutuhan zat besi masih kekurangan untuk wanita hamil (Manuaba, 2013).

Berdasarkan pendapat para ahli diatas, menunjukan bahwa kebutuhan zat besi pada masa hamil sangat memberikan kontribusi positif terhadap kesehatan ibu dan janin, ibu hamil yang kurang mengkonsumsi tablet Fe akan berdampak pada kejadian anemia yang akhirnya menyebabkan terjadinya perdarahan pada saat melahirkan. Ada hubungan yang erat antara mengkonsumsi tablet Fe dengan kejadian perdarahan, lebih - lebih pada trimester III karena masa ini merupakan masa yang paling rutin untuk dijaga.

Peneliti menganalisa bahwa dampak anemia dalam kehamilan adalah dapat terjadi keguguran. Dampak anemia dalam persalinan adalah kelahiran premature, inertia uteri, atonia uteri, partus lama, perdarahan atonis dan kelahiran dengan BBLR (Berat Bayi Lahir Rendah) dengan kondisi bayi yang lemah. desangkan Dampak anemia pada masa nifas adalah subinvolusio rahim, daya tahan terhadap infeksi, produksi ASI rendah dan stress. Kepatuhan mengkonsumsi tablet Fe, selain memberikan dampak positif juga memberikan dampak negatif bagi ibu hamil yang tidak patuh mengkonsumsinya. Dengan hasil penelitian ini menunjukan hubungan kepatuhan mengkonsumsi tablet Fe dengan kejadian perdarahan pada pasca persalinan sangatlah signifikan atau erat hubungannya.

\section{KESIMPULAN DAN SARAN}

Hasil Analisis statistik dengan uji Chi Squart test menunjukkan bahwa nilai $p=0,03$ dan nilai $\alpha=0,05$ yang berarti $p<\alpha$ dengan demikian Ho ditolak dan Ha diterima, berarti dapat disimpulkan bahwa ada hubungan antara kepatuhan mengkonsumsi tablet $\mathrm{Fe}$ dengan tingkat kejadian perdarahan pada ibu hamil trimester III. Sarandiharapkan hasil penelitian ini dapat memberikan ilmu yang baru untuk menelaah lebih lanjut kepatuhan mengkonsumsi tablet Fe 
Hubungan Antara Kepatuhan Mengkonsumsi Tablet Fe Dengan Tingkat Kejadian Perdarahan Pada Ibu Hamil Trimester III

\section{Daftar Pustaka}

Alan H, Decherney, 2011. Pedoman Klinis Keperawatan Pediatric. Edisi 4, EGC:Jakarta.

Arisman, 2009. Hubungan Pengetahuan Orang Tua Tentang StimulasiUsia Dini Dengan Tingkat Perkembangan Anak Usia 1-3 Tahun (Toddler) Diwilayah Kerja Puskesmas Tamanlarea Kota Makassar.PSIK Universitas Hasanuddin: Makassar.

Baker, 2011. Kehamilan dan nutrisi kehamilan yang dibutubkan. Karya cipta : Surabaya.

Dinas kesehatan propinsi NTB,Laporan tabunan. 2014.

Kusmiyati, 2013 Metodologi Penelitian Kesehatan. Edisi revisi, Salemba Medika: Jakarta.

Manuaba, 2014.Buku Ajar Konsep Dasar Keperawatan Anak. EGC : Jakarta.

Prawirohardjo, 2010. Antisipasi Pendarahan Kehamilan. Rosdakarya : bandung.

Puskesmas Woha, Laporan bulanan2016.

Ramanathan, G, 2012.Teori Dan Pengukuran Pengetabuan, Sikeap DanPerilaku Manusia. Nuha Medika: Yogyakarta.

Saifuddin, 2015. Kehamilan dan nutrisi kehamilan. Rosdakarya : bandung. Varney, 2016. Statistik Untuk. Kedokteran Dan Kesehatan. Salemba Medika:Jakarta.

Winkjosastro, 2013. Imu Pendidikan Teoritis. Intima:Jakarta. 